\title{
Growing Dependence on Transfers and Rising Disparity in Municipal Finances in India: Evidence from Thirteenth Finance Commission
}

\author{
Debdulal Thakur \& Shrabani Mukherjee ${ }^{1}$ \\ Faculty, Department of Economics Birla Institute of Technology \& Science (BITS) Pilani University \\ K.K.Birla Goa Campus Near NH-17-B, Bye Pass Road Zuari Nagar, Goa-403726
}

\begin{abstract}
Accepting the increasing role of the urban local bodies (ULBs) in India, many studies point out to the low performance and infancy of the ULBs in regard to fiscal solvency. This is largely attributed to the state policies and ad-hoc transfer mechanism. Using the dataset (1998/99 to 2007/08) of the Twelfth and Thirteenth Finance Commission the present paper attempts to understand the underlying reason for such ill performance. The paper shows that the problem is even greater as many of the top states could not even keep pace with the rising demand for expenditure provisions at par with urbanization. Using five suitable measures the paper further tries to gauge the reason for this growing dependence on transfers and rising disparity in municipal finances for 17 major states in India and questions the fundamental role the state plays.
\end{abstract}

Key words: India, Urban local body, Revenue, Expenditure, Intergovernmental Transfers, Disparity

JEL Codes: H71, H73, H77, RO, R51, R58

\section{Introduction}

It was thought that after the enactment of the $74^{\text {th }}$ Constitutional Amendment Act, by virtue of decentralization, the urban economy would have a firm foot having powers of taxation, providing urban services on its own and alike. It was thought that the local bodies would indeed act like any other self sustained constitutional tier of the government. The urban economy is estimated to contribute around 62 percent of the Gross Domestic Product (GDP) during 2009/10. Indeed commendable, but question arises, if at all this contribution to GDP by the urban local bodies (ULBs) across states is normally distributed? If not, then there is enough room to suspect the expected development of these ULBs spread across 29 states. Simply because, in this federal structure it was the task of this third tier government to bridge the gap between per capita availability of public resources.

To support these initiatives and reduce the vertical gap, in the wake of the $74^{\text {th }}$ Constitutional Amendment Act (CAA), the State Finance Commissions (SFCs) were set up by all state governments to spell out the principles for sharing/devolving a part of the revenue of the state government to local governments. Further, the Central Finance Commission (CFC) funds are also disbursed by the state governments. The expectation was that SFCs will follow the worthy example of the CFC which performs this task of devolution of funds from the Government of India (GOI, henceforth) to state governments, but this has not happened ([1]) Similar examples can be cited in terms of the declining share of own revenues and rising demand for expenditure for the urban local bodies over the years.

All this taken together has made the urban economy much dependent on the state exchequer, an agenda contrary to the basic idea for the third tier of government. With these features the urban economy has only pumped the notion of inequality- be it its revenue raising capacity or be it the expenditure capacity. Eventually, in terms of the state transfers too, the above phenomenon became a regular feature.

The present paper now attempts to get evidences of this rising disparity among the urban local bodies spread across 17 major states using data from $1998 / 99$ to $2007 / 08$ as has been provided by the $12^{\text {th }}$ and $13^{\text {th }}$ Central Finance Commissions ([2],[3]). This study, specifically, articulates the inequality by using five different measures, thereby toothcombing the underlying reasons, tries to explore the needed policy priority. The paper is divided into five sections including this introductory part and conclusion. Followed by this section, the second section reviews the related literatures. The third section briefly overviews the Indian scenario in terms of municipal finances via the 'coefficient of dependency', urbanization vis-a vis expenditure trends etc. Fourth section attempts to investigate on the magnitude of rising disparity across municipalities in India using different measures of inequality. The Empirical results have been explained thereafter followed by the conclusion.

\footnotetext{
${ }^{1}$ Authors are arranged in alphabetical order. Opinions made in this write up are personal and are not binding upon any individual or institute.
} 


\section{Review of Literature - Indian Scenario}

The challenges of urbanization, of higher rates of economic growth, shifting composition of growth towards increasingly urban-based economic activities, and increasing global competition are unprecedented in scale and complexity with enormous implications for municipal governments. An effective response to these challenges require designing a municipal fiscal policy and strategy that can meet the long-term economic growth and welfare needs ,delineating the respective roles of the three tiers of government in financing urban development and services, and establishing fiscal rules that are consistent with the changing socio-economic realities.

The existing patterns of fiscal arrangements are inadequate for this purpose. Commenting on the Indian system ([4]) remarks that open multicultural policies support cosmopolitanism and attract both capital and labour, in contrast, restrictive policies create insecurity and prevent efficient migration. The latter being the case for India. But, as the country urbanizes, cities will be required to respond to the preferences of citizens business and industry by addressing growth-welfare equations. How India responds to such demands for infrastructure and services is a question of what model of municipal finance will be pursued in the future. What is unquestionable is the scale and scope of urban transition, and the vast financial resources that will be needed for its management. But the policies that are opted in a three tier federal structure in India are not beyond criticism. It is quite well known that as a part of 'fiscal responsibility' the revenue instruments assigned to a tier of government should match, as far as possible, the expenditure requirements ([5], [6]). However, in reality, the mismatch in functions and finance is the major issue in fiscal decentralization. These discrepancies gave birth to unequal fiscal capacities. Citing evidences from the economic history of India, it has been observed uniform assignment system in an unevenly endowed federating system resulted in large differences in fiscal capacities ([7]). They argued that varying sizes of states in terms of area and population, demographic compositions, different terrain and topography caused significant variations in the unit cost of providing public services, varying expenditure needs and placed a heavy burden of equalization on the intergovernmental transfer system. We must recall at this moment that the traditional understanding of intergovernmental grants and tax sharing comes from welfare economics. It assumes that a benevolent omniscient central government assigns expenditure and revenue authority according to efficiency criterion and that grants serve purposes of efficiency and redistribution ([4], [8]). Indeed the ability of the higher tiers of government to use grants to overcome problems of externalities and inequality is central to any normative conception of multilateral government. However, in practice, higher tier governments may be vulnerable to tendencies of political economy and rent seeking elsewhere, and systems of transfers and revenue sharing may thus cause inefficient responses that are not foreseen quite easily. On a ceteris-paribus assumption, intergovernmental transfers encourage the provision of local government services. It might also increase private sector demand and even lead to the reduction of taxation. Whether grants will stimulate more positive impact or reduce local taxation or produce other effects is an empirical question. Empirical evidences suggests that matching grants, particularly of the open-ended variety, have greater stimulating effect on grant-receiving institutions because of both income and substitution effects, on the contrary closed ended grants stimulate greater expenditure than the former kind ([9], [10]).

The core problem with this type of grants is that it may distort local priorities. It is also likely to widening spatial disparities as richer governments would attract more resources especially under an open-ended grant programme. This has very serious implications for countries like India where reducing spatial disparities has been an avowed development objective of the Government. With the enactment of the 74th CAA greater autonomy and responsibilities for elected Municipalities for promoting social and economic development of the country came into place. However, true that autonomy and discharging the responsibilities require greater access to resources, but the institutional mechanisms in place, even as of now, are not adequate to ensure a match between municipal functions and finances ([5]). Particularly for the urban India the share of own revenues in total revenues has declined and in many municipal bodies where ULBs are virtually reduced to becoming state government departments since even the salaries are paid by the state governments ([1]). Given the limitations to raise own resources, there is a strong argument for institutionalizing resource flow from the higher level of Governments to ULBs based on principles. However, the issues of intergovernmental transfers to local bodies have not received due attention in India owing to a variety of reasons and therefore remain discretionary in nature. These transfers are neither based on any normative analysis nor are they predictable. They are rather adhoc sources of revenue for the Municipalities ([5], [11]). This contrasts the fact that the transfers from the centre to states based on the recommendations of the CFCs have always been determined by objective formulae. All these taken together has made a clear divide between the states situated in the western, southern part of India and the states situated in the northern and eastern part of India. 


\section{Revenue trends of ULBs}

The revenue base of municipalities in Indian states has shown little signs of change, notwithstanding the Constitution (seventy-fourth) Amendment Act, 1992; indeed, abolition of octroi highly liquid source of revenue for municipalities, without being substituted by any other local source, has substantially dented the revenue base of municipalities. It is important to point out that while the municipal revenue base in India may fulfill the criteria for the determination of a local tax base, e.g., the principles of residence and benefit taxation, low mobility, and stability over the period of business cycle, and while it may even create a link between service use and tax payment, it is controlled and regulated by state governments.

Until the passage of the Constitution (seventy-fourth) Amendment Act, 1992, the municipal affairs were an exclusive concern of the state governments. Drawing strength from the Constitutional provisions, the state governments determined the expenditure responsibilities and fiscal powers and authority of municipalities, and defined the degree of autonomy within which they could function. Discussions on how to improve the financial viability of municipalities or streamline the flow of funds to them, or carry out reform of municipal taxes took place within the parameters of state control over municipalities. In principle, the state governments assumed responsibility for the financial viability of municipalities, using transfers as an instrument for bridging the gap between what the municipalities needed to carry out the mandated functions and what their revenue powers yielded, as also for meeting the financial needs of municipalities with cost disadvantages.

Transfers to municipalities in the pre-amendment period accrued under two major heads: transfers through the tax sharing arrangement and grants.Tax sharing arrangements specified, how and in what proportion the state level taxes were to be shared with the municipal governments. Tax sharing arrangements were thus different from the use of the same tax base being tapped by the different levels of governments. The second, widely prevalent form of transfers in India was via grants. Grants were non-matching, general or unconditional, specific-purpose or conditional, and compensatory, i.e., given in lieu of tax bases abolished by the higher levels of governments. Some grants also required matching contributions from the municipal governments.

The size of the municipal sector in terms of what they raise via their own revenue efforts is tiny, around 0.50 percent of the gross domestic product (GDP). Over the period 1998/99 to 2007/08, however, the size of the municipal sector has registered a marginal expansion, both in terms of its share in the total publicly-raised revenues and combined GSDP. Municipal share in the total revenues of the three tiers of government has risen from 2.39 per cent in 1998-99 to 2.86 per cent in 2001-02. However, from 2003-04 onwards we see a falling trend of municipal own revenues- from 2.72 percent to 2.09 percent in 2007-08 (Table 1).

Table 1: Revenue significance of municipalities

\begin{tabular}{|c|c|c|c|c|c|}
\hline \multirow{2}{*}{ Year } & \multirow{2}{*}{$\begin{array}{l}\text { Municipalities } \\
\text { own revenue } \\
\text { (Rs. Crore) }\end{array}$} & \multirow{2}{*}{$\begin{array}{l}\text { Per cent of } \\
\text { combined } \\
\text { GSDP }\end{array}$} & \multicolumn{3}{|c|}{$\begin{array}{l}\text { Share of the different tiers in publicly raised } \\
\text { resources }(\%)\end{array}$} \\
\hline & & & Municipalities & $\begin{array}{l}\text { State } \\
\text { governments }\end{array}$ & $\begin{array}{l}\text { Central } \\
\text { government }\end{array}$ \\
\hline $1998 / 99$ & 6873.47 & 0.42 & 2.39 & 44.92 & 52.69 \\
\hline $1999 / 00$ & 7379.85 & 0.41 & 2.18 & 43.53 & 54.29 \\
\hline $2000 / 01$ & 8260.49 & 0.43 & 2.17 & 45.07 & 52.77 \\
\hline $2001 / 02$ & 8760.16 & 0.42 & 2.20 & 47.74 & 50.06 \\
\hline $2002 / 03$ & 13279.97 & 0.59 & 2.86 & 45.43 & 51.71 \\
\hline $2003 / 04$ & 14440.71 & 0.57 & 2.72 & 44.82 & 52.46 \\
\hline $2004 / 05$ & 16285.89 & 0.57 & 2.56 & 44.56 & 52.88 \\
\hline $2005 / 06$ & 18235.19 & 0.56 & 2.41 & 43.96 & 53.63 \\
\hline $2006 / 07$ & 20830.05 & 0.55 & 2.26 & 41.87 & 55.87 \\
\hline $2007 / 08$ & 23521.38 & 0.54 & 2.09 & 37.87 & 60.05 \\
\hline
\end{tabular}

Source: [2] , [3] , [12]; Note: The above table does not include the Union Territories

Municipal own revenues (nominal terms) have risen at a compound average growth rate (CAGR) of 13.09 per cent $^{2}$. As a proportion of the combined gross domestic product of states (GSDP), aggregate municipal expenditures have also risen from 0.88 per cent in 1998/99 to 1.09 per cent during 2007/08. A break up of this expenditure would reveal that though as a percent of combined GSDP revenue expenditure remained almost stagnant during the study period, but its share in total expenditure remained much higher then capital expenditure. Though of late due to rapid urbanization and reform processes like the JNNURM the share of

\footnotetext{
${ }^{2}$ This growth, as we shall see a little later, is attributed mainly by the growth of own revenues in major urban centers like Mumbai, whereas in fact the dispersion in own revenue across municipalities has actually increased over time. To note that the annual budget of the Greater Mumbai Municipal Corporation is larger then the state budget of Orissa. The rest can be well assumed.
} 
capital expenditures has been rising in the current years. During 2007/08, 40 percent of the total expenditures incurred by the ULB accrue to capital expenditures. But, creating assets is not the end of the reform process, as funds are needed to maintain in the long run as well. Therefore, it is quite obvious that the ULBs need to generate funds from their own sources, rather than banking upon the state exchequer for an endless period.

.As evident from the Table 2, that out of the 17 study states 13 register a fall in their own revenue as a percentage to the non-primary GSDP during 2007/08 compared to 1997/98. Further, it is also seen that 12 register a rise in their revenue receipts and 13 register a rise in total expenditure - all seen as a percentage of the non-primary GSDP. Total revenues include transfers, assigned taxes and grants in addition to own revenues The above scenario in a way depicts the fiscal dependency of the ULB's on their respective provincial governments in majority of the cases. An explanation of this low collection could be attributed to the low collection of property taxes - the main source of own revenue for ULBs in India. To note, the all India collection efficiency of property tax is 37 percent ([11]). This essentially means that though an important source of revenue, perhaps the only one for majority of the ULBs in India is still neglected and thus the ULB finding the state an easy option to fall back are still enjoying infancy. States like Maharashtra, Madhya Pradesh, Gujarat the growth in own revenue as a percent of their NPGSDP has risen over the period in concern, and that too to a commendable extent. For example for Madhya Pradesh during 2007/08 own revenue as a percent of NPGSDP recorded a figure of 3.94 percent as against 1.93 percent during 1997/98. On the other hand for states like Orissa the same has actually fallen during 2007/08 (0.03 percent, the lowest figure for the 18 study states) compared to $1997 / 98$ ( 0.15 percent). The dispersion is quite evident. This variation in the own source revenue compels the ULBs to rely upon the transfers.

Table 2:Inter-state difference in finances of the ULBs during 2001/02

\begin{tabular}{|c|c|c|c|c|c|c|c|c|c|c|}
\hline \multirow[t]{2}{*}{ States } & \multicolumn{2}{|c|}{$\begin{array}{l}\text { Own } \\
\text { Revenue } \\
\text { as a \% } \\
\text { of NPGSDP }\end{array}$} & \multicolumn{2}{|c|}{$\begin{array}{l}\text { Total } \\
\text { Revenue } \\
\text { as a \% of } \\
\text { NPGSDP }\end{array}$} & \multicolumn{2}{|c|}{$\begin{array}{l}\text { Revenue } \\
\text { Expenditure } \\
\text { as a \% of } \\
\text { NPGSDP }\end{array}$} & \multicolumn{2}{|c|}{$\begin{array}{l}\text { Capital } \\
\text { Expenditure } \\
\text { as a \% of } \\
\text { NPGSDP }\end{array}$} & \multicolumn{2}{|c|}{$\begin{array}{l}\text { Total } \\
\text { Expenditure } \\
\text { as a \% of } \\
\text { NPGSDP }\end{array}$} \\
\hline & $1997 / 98$ & $2007 / 08$ & $1997 / 98$ & $2007 / 08$ & $1997 / 98$ & $2007 / 08$ & $1997 / 98$ & $2007 / 08$ & $1997 / 98$ & $2007 / 08$ \\
\hline $\begin{array}{l}\text { Andhra } \\
\text { Pradesh }\end{array}$ & 0.68 & 0.74 & 0.99 & 1.21 & 1.06 & 1.05 & 0.29 & 0.63 & 1.34 & 1.68 \\
\hline Assam & 0.15 & 0.13 & 0.21 & 0.34 & 0.22 & 0.18 & 0.04 & 0.21 & 0.26 & 0.39 \\
\hline Bihar & 0.16 & 0.12 & 0.18 & 0.78 & 0.26 & 0.82 & 0.10 & - & 0.37 & 0.82 \\
\hline Chhattisgarh & 0.69 & 0.36 & 1.37 & 2.53 & 0.97 & 1.38 & 0.48 & 1.20 & 1.45 & 2.58 \\
\hline Gujarat & 1.38 & 0.99 & 1.81 & 1.61 & 0.87 & 1.04 & 0.43 & 0.72 & 1.30 & 1.76 \\
\hline Haryana & 0.28 & 0.18 & 0.38 & 0.54 & 0.21 & 0.21 & - & 0.31 & 0.21 & 0.52 \\
\hline Jharkhand & 0.14 & 0.11 & 0.31 & 0.55 & 0.08 & 0.17 & 0.44 & 0.38 & 0.52 & 0.55 \\
\hline Karnataka & 0.57 & 0.57 & 1.41 & 1.67 & 0.51 & 0.79 & 0.26 & 1.00 & 0.76 & 1.79 \\
\hline Kerala & 0.36 & 0.20 & 0.52 & 0.51 & 0.70 & 0.32 & 0.24 & 0.22 & 0.94 & 0.54 \\
\hline $\begin{array}{l}\text { Madhya } \\
\text { Pradesh }\end{array}$ & 1.93 & 3.94 & 3.07 & 5.61 & 1.90 & 1.81 & 0.27 & 0.56 & 2.17 & 2.37 \\
\hline Maharashtra & 1.09 & 2.41 & 1.48 & 3.17 & 0.69 & 2.08 & 0.28 & 1.24 & 0.96 & 3.32 \\
\hline Orissa & 0.15 & 0.03 & 0.58 & 0.71 & 0.61 & 0.34 & - & 0.37 & 0.61 & 0.71 \\
\hline Punjab & 1.38 & 1.07 & 1.53 & 1.20 & 0.84 & 0.94 & 0.30 & 0.24 & 1.13 & 1.18 \\
\hline Rajasthan & 0.30 & 0.47 & 1.30 & 1.18 & 0.93 & 0.54 & 0.33 & 0.45 & 1.26 & 0.99 \\
\hline Tamil Nadu & 0.75 & 0.51 & 1.25 & 1.34 & 1.22 & 0.86 & 0.54 & 0.64 & 1.77 & 1.50 \\
\hline Uttar Pradesh & 0.23 & 0.15 & 0.83 & 1.03 & 0.87 & 0.40 & 0.06 & 0.34 & 0.93 & 0.74 \\
\hline West Bengal & 0.43 & 0.41 & 1.12 & 0.80 & 0.80 & 0.60 & 0.12 & 0.40 & 0.92 & 1.00 \\
\hline Mean & 0.60 & 0.69 & 1.04 & 1.39 & 0.73 & 0.75 & 0.23 & 0.50 & 0.96 & 1.25 \\
\hline
\end{tabular}

Note: NPGSDP: Non Primary Gross Domestic Product; A blank cell signifies non-availability of data. Source: Non-Primary GSDP calculated from the data provided by the Central Statistical Organization, Government of India ([13]). For details refer to http://mospi.nic.in/Mospi_New/site/home.aspx ; Revenue \& Expenditure data compiled from 'Report of the Twelfth Central Finance Commission' and 'Report of the Twelfth Central Finance Commission', Government of India, New Delhi, India ([2], [3]) . 


\section{Coefficient of Dependency}

A supplementary test of the above argument could be made possible by calculating the coefficient of dependency $(\mathrm{COD})^{3}$. The measure would suggest that a coefficient of 'zero' would indicate absolute state dependency of the local governments in terms of expenditure needs; where as a coefficient of 'one' would indicate otherwise. Here (refer to Chart 1)we see that in comparison to 1998/99 the COD for most of the states excepting Rajasthan and Maharashtra has rather deteriorated. One reason for explaining this greater dependency on the state exchequer could be the withdrawal of octroi from the own source category and instead providing a compensation in lieu of the same from the state exchequer.

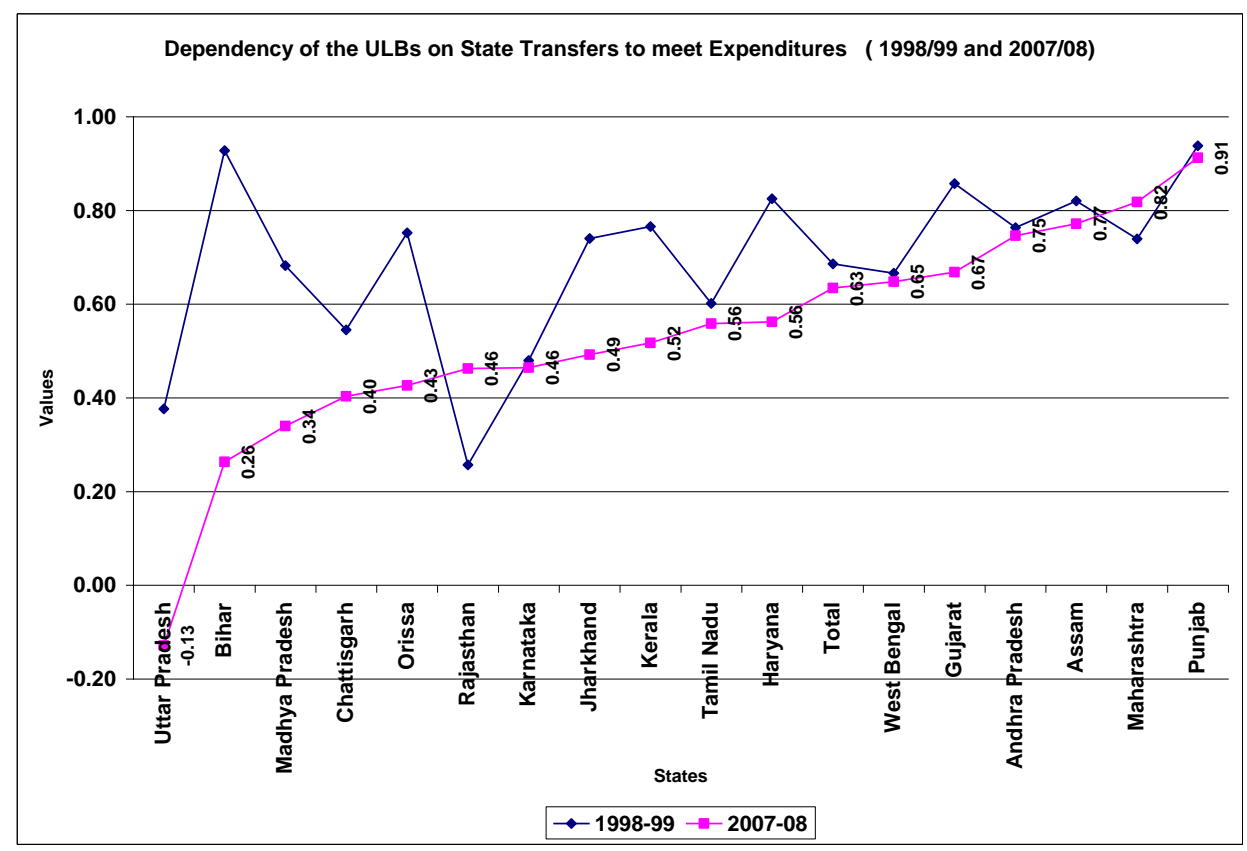

Figure 1: Dependency of the ULBs on state transfers to meet expenditure needs during $1998 / 99$ and 2007/08

Source: Calculated on the basis of data provided by Report of the Twelfth Central Finance Commission and Report of the Twelfth Central Finance Commission, Government of India, New Delhi, India ([2] , [3]).

For the state of Rajasthan, it still treats octroi compensation as its own revenue since they believe, so is the improvement in the COD, as in terms of its own revenue collection the figure is not at all impressive. Now the above chart clearly shows that there is indeed reason to suspect that the ULBs could not substitute the revenue collection which was earlier incurred from Octroi with their present available own revenue sources- the prime being property tax. Indeed that could be, as in India out of every 100 Rupees demanded for property tax only Rs.37 gets collected ([11]). The loss due to inefficiency in terms of collection is quite prominent.

Next we turn to the issue of expenditure and state transfers. Here for all these 17 states we tried to calculate the share of expenditure for each state as a percent of total expenditure incurred for these 17 states for the two benchmark years. Similarly, we calculated the share of state transfers for each of them as a percentage of total transfers disabused to all these 17 states. This is to see the proportion of spending and transfers in regard to each state when compared to the aggregate of all these 17 states.

Table 3: Trend in share of expenditure \& state transfers between 199/99 and 2007/08

\begin{tabular}{|l|l|l|l|l|l|l|}
\hline \multirow{2}{*}{ States } & \multicolumn{2}{|l|}{ Expenditure Shares } & \multicolumn{2}{l|}{ Share in State Transfers } \\
\cline { 2 - 6 } & $\mathbf{1 9 9 8 - 9 9}$ & $\mathbf{2 0 0 7 - 0 8}$ & $\begin{array}{l}\text { Difference of } \\
\text { percentage } \\
\text { points in } \\
\text { Expenditure } \\
\text { Share }\end{array}$ & $\mathbf{1 9 9 8 - 9 9}$ & $\mathbf{2 0 0 7 - 0 8}$ & $\begin{array}{l}\text { Difference } \\
\text { of } \\
\text { percentage } \\
\text { points in } \\
\text { State }\end{array}$ \\
\hline
\end{tabular}

${ }^{3} \mathbf{C O D}=\mathbf{1}-(\mathbf{B}+\mathbf{C}) / \mathbf{D}$, Where $\mathrm{A}=$ Total revenue receipts excluding any grants $\&$ transfers; $\mathrm{B}=$ Transfers $=$ Grants from state governments $C=$ Net Borrowing of the ULBs $=-(A-D) ; D=$ Expenditure of the ULBs= Total Expenditure \& Lending - Repayments 
Growing Dependence on Transfers and Rising Disparity in Municipal Finances in India:

\begin{tabular}{|l|l|l|l|l|l|l|}
\hline & & & & & & Transfers \\
\cline { 2 - 7 } & $\mathrm{A}$ & $\mathrm{B}$ & $\mathrm{C}=\mathrm{B}-\mathrm{A}$ & $\mathrm{D}$ & $\mathrm{E}$ & $\mathrm{F}=\mathrm{E}-\mathrm{D}$ \\
\hline Andhra Pradesh & 6.91 & 8.25 & 1.34 & 5.21 & 5.73 & 0.52 \\
\hline Assam & 0.30 & 0.39 & 0.09 & 0.17 & 0.25 & 0.07 \\
\hline Bihar & 0.75 & 1.50 & 0.75 & 0.17 & 3.02 & 2.85 \\
\hline Chattisgarh & 0.94 & 3.00 & 2.07 & 1.36 & 4.90 & 3.54 \\
\hline Gujarat & 15.39 & 9.20 & $\mathbf{- 6 . 1 8}$ & 6.98 & 8.35 & 1.36 \\
\hline Haryana & 1.32 & 1.34 & 0.02 & 0.74 & 1.60 & 0.87 \\
\hline Jharkhand & 0.15 & 0.64 & 0.49 & 0.12 & 0.88 & 0.76 \\
\hline Karnataka & 6.66 & 7.63 & 0.97 & 11.03 & 11.18 & 0.14 \\
\hline Kerala & 3.54 & 1.64 & $\mathbf{- 1 . 9 0}$ & 2.64 & 2.16 & $\mathbf{- 0 . 4 8}$ \\
\hline $\begin{array}{l}\text { Madhya } \\
\text { Pradesh }\end{array}$ & 10.21 & 5.27 & $\mathbf{- 4 . 9 4}$ & 10.34 & 9.51 & $\mathbf{- 0 . 8 3}$ \\
\hline Maharashtra & 20.62 & 37.32 & 16.70 & 17.13 & 18.60 & 1.47 \\
\hline Orissa & 0.63 & 1.18 & 0.55 & 0.50 & 1.85 & 1.35 \\
\hline Punjab & 4.31 & 2.46 & $\mathbf{- 1 . 8 5}$ & 0.85 & 0.59 & $\mathbf{- 0 . 2 6}$ \\
\hline Rajasthan & 3.61 & 2.70 & $\mathbf{- 0 . 9 1}$ & 8.54 & 3.98 & $\mathbf{- 4 . 5 7}$ \\
\hline Tamil Nadu & 11.80 & 8.41 & $\mathbf{- 3 . 3 9}$ & 14.98 & 10.16 & $\mathbf{- 4 . 8 2}$ \\
\hline Uttar Pradesh & 6.02 & 4.01 & $\mathbf{- 2 . 0 1}$ & 11.96 & 12.39 & 0.43 \\
\hline West Bengal & 6.85 & 5.05 & $\mathbf{- 1 . 8 0}$ & 7.29 & 4.86 & $\mathbf{- 2 . 4 3}$ \\
\hline
\end{tabular}

Source: Calculated on the basis of data provided by Report of the Twelfth Central Finance Commission and Report of the Twelfth Central Finance Commission, Government of India, New Delhi, India ([2], [3]).

Table 3 shows that for states like Gujarat, Kerala, Madhya Pradesh, Orissa, Punjab, Rajasthan, Tamil Nadu, Uttar Pradesh and West Bengal the expenditure share has actually fallen by considerable percentage points. Since here we have considered total expenditure which comprises both revenue and capital; expenditures, so a fall in total expenditure would either mean expenditure reduction in terms of revenue expenditure, or a reduction in capital expenditure or both. However, in the wake of JNNURM and other infrastructure investments in most of the said states must have boosted the capital expenditure or at least it remained stable. Further, capital expenditures are discretionary in nature. Therefore, the reduction points to a reduction in revenue expenditure. This might happen under two scenarios- either there has been a reduction in the committed expenditure part- due to massive retirement and non recruitment or the operation and maintenance of services has taken a back seat. Even if we consider the fall in expenditure as a result of massive retirement and non-recruitment even then operation and maintenance suffers due to lack of human resources Therefore, such reduction implies that operation and maintenance suffers a 'double disadvantage'. However, if we add up the findings of the RIUIS ([1]) then the already low spending for operation and maintenance clubbed with the above argument, points out that operation and maintenance suffers a 'triple disadvantage' instead.

As also evident from the above chart that for few states both expenditure share and share of state transfers has fallen. These states needs added attention, no doubt, as the magnitude and complexity of the municipal finance certainly needs further investigation.

\section{Does expenditure and urbanization have similar pace?}

For 10 select states placed in order of urbanization we calculate the difference in percentage points of expenditure incurred between two time periods, 1998/99 and 2007/08. The findings (Figure 2) below provide a view of the findings. We see that keeping pace with urbanization only Maharashtra, Karnataka, Haryana and Andhra Pradesh shows an increase in expenditure share in comparison to all top 10 states. Therefore, perhaps it is high time we try to make an attempt to investigate the cause/s of these low spending. What really explains such features? Is it so that the transfers over the periods failed to reduce the gap in terms of their expenditure capacity or did the ULBs failed to raise their revenue generating capacity- no matter even if they are still very low? If yes, then where lies serious problem. Is it a problem of improper expenditure management or inappropriate policies? Or is it the inefficiency of the ULBs? What really explains such unequal performances of municipal finance? 


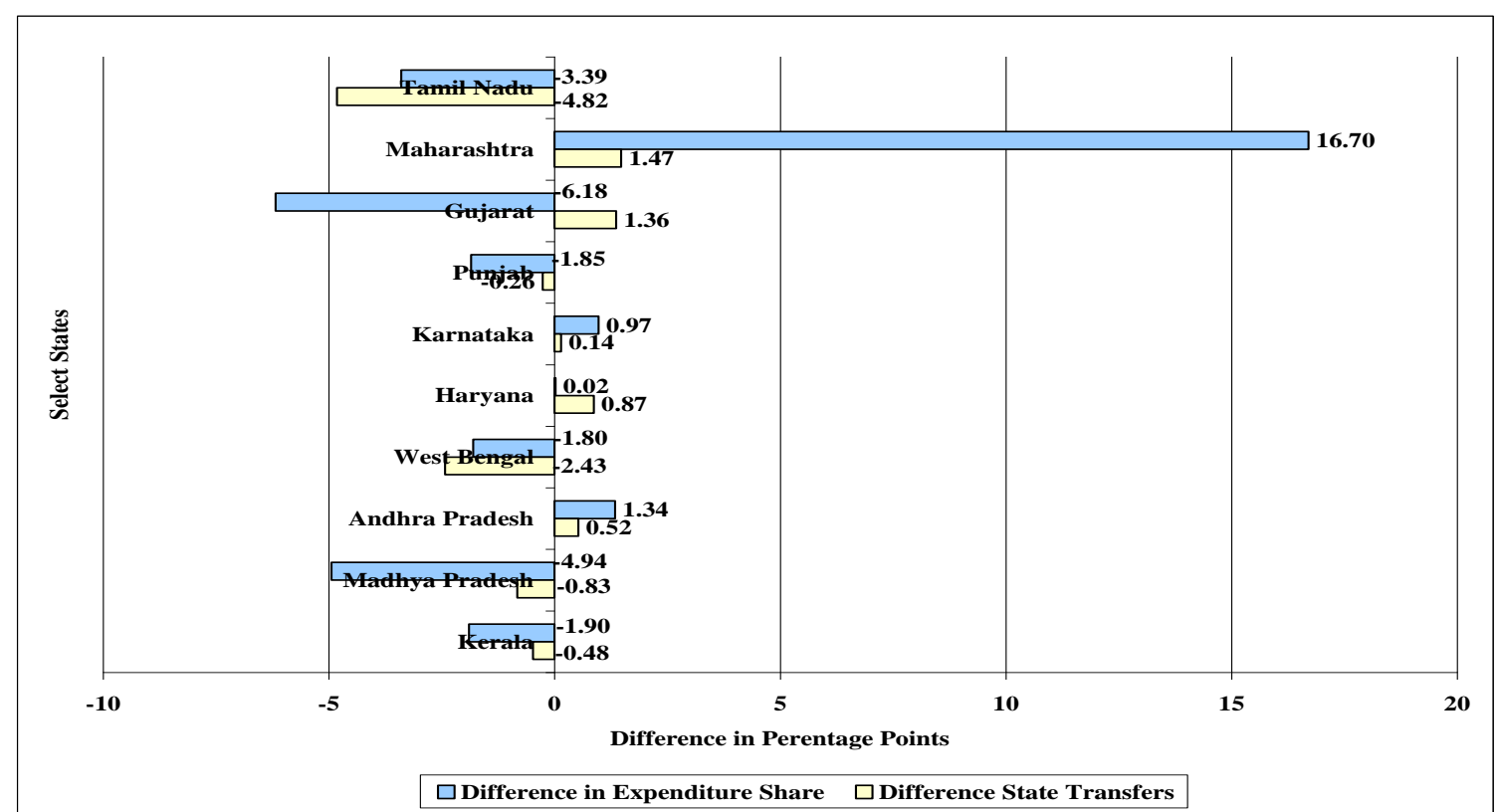

Figure 2: Difference in the share of expenditure $\&$ state transfers in relation to urbanization during between 1998/99 and 2007/08 for select states (percentage points)

Note: States are arranged in order of their urbanization trend in an ascending order starting from Kerala. Source: [1]; Table 3: Trend in share of expenditure \& state transfers between 199/99 and 2007/08, above.

\section{On Rising Disparity: Data \& Methodology}

.In order to get the vertical imbalances (state wise inequality) in input-output ratios we have estimated coefficient of variation for the years 2001-02 to 2007-08. Coefficient of variation (CV) is defined as a normalized measure of dispersion of a probability distribution. It is also known as unitized risk or the variation coefficient.

$\mathrm{CV}=$ Slandered Deviation / Mean

Where, the standard deviation of an exponential distribution is equal to its mean, so it's $\mathrm{CV}=1$. Distributions with $\mathrm{CV}<1$ (such as an Erlang distribution) are considered low-variance, while those with $\mathrm{CV}>1$ (such as a hyper-exponential distribution) are considered high-variance.

Again we have estimated state wise disparity by another measure of inequality, viz., Generalized Entropy class of measures which is defined by a general formula as follows:

$$
G E(\gamma)=\frac{1}{\gamma^{2}-\gamma}\left[\frac{1}{n} \sum_{i=1}^{n}\left(\frac{x_{i}}{\bar{x}}\right)^{\gamma}-1\right] .
$$

Where $n$ is the number of states in the sample, $x_{i}$ is the income or expenditure of state $i, \bar{x}$ is the arithmetic mean income. The value of GE ranges from 0 to $\infty$, with zero representing an equal distribution and higher values representing higher levels of inequality. The parameter $\gamma$ in the GE class represents the weight given to distances between incomes at different parts of the income distribution, and can take any real value. For lower values of $\gamma$, GE is more sensitive to changes in the lower tail of the distribution, and for higher values GE is more sensitive to changes that affect the upper tail. The third measure of inequality is the Atkinson class of measures which is defined as:

$$
A_{\rho}=1-\left[\frac{1}{n} \sum_{i=1}^{n}\left(\frac{x_{i}}{\bar{x}}\right)^{1-\rho}\right]^{\frac{1}{1-\rho}}
$$

The Atkinson class of measures range from 0 to 1 , with zero representing no inequality. Setting $\gamma=1-\rho$ the GE class becomes ordinally equivalent to the Atkinson class, for values of $\gamma<1$ ([14]).

Lastly, we have calculated the Gini coefficient measures which is defined as

$$
\text { gini }=\frac{1}{2 n^{2 \bar{x}}} \sum_{i=1}^{n} \sum_{j=1}^{n}\left[x_{i}-x_{j}\right] .
$$

The Gini coefficient takes on values between 0 and 1 with zero interpreted as no inequality. Therefore, here in an attempt to understand the persistent inequality in the municipal finance system we try to measure the inequality with five different measures. The idea is to see if at all they give similar results or otherwise. For results with dissimilar magnitude would either point to the non-reliability of the data or to the fact that there remains ample room for unexplained factors that brings out such divergent outcome. Nevertheless, for the estimation we have chosen per capita own revenue receipts (PCOR), per capita state transfers (PCST) and per 
capita total expenditure (PCTE). The underlying assumption to choose these three variables is simple. In a sense we assume that the per capita own revenue resembles the revenue raising capacity, where as the per capita revenue expenditure resembles the expenditure capacity for the respective ULBs within the states. Similarly, per capita state transfers resemble the revenue sharing priority of the state in regard to its urban mass.

\section{Measuring disparity-Empirical Results}

To begin with we first plot the coefficient of variation in regard to per capita own revenue, per capita state transfers and per capita revenue expenditure. As mentioned that revenue expenditure contains the expenditure meant for the recurring establishment and also for the operation and maintenance for the basic services that the ULBs should provide as per the $74^{\text {th }}$ CAA.

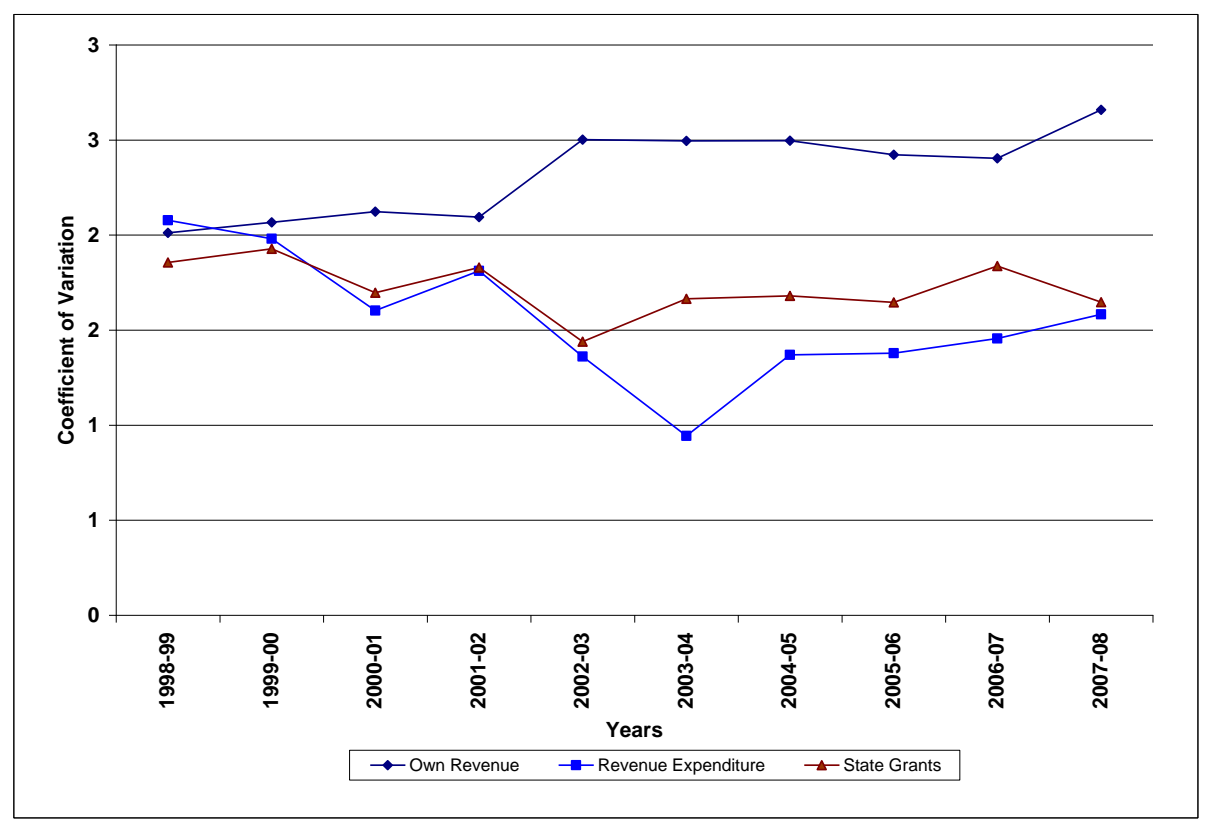

Figure 3: Coefficient of variation in per capita receipts \& expenditure of the ULBs for the study states Source: [2], [3], [15] (percent)

Figure 3 clearly resembles that the inequality in regard to all the indicators has actually risen over the successive years. The rise is rather prominent after 2003/04 for the State transfers and revenue expenditure. On the other hand coefficients of variation for own revenues maintained a rising trend from 1997/98 till 2002/0. Then it stagnated between $2002 / 03$ to $2004 / 05$ and then after a slight decrease till $2006 / 07$, it started rising again. Therefore, in totality we can see that there has been a rising trend of inequality among the study states- be it the revenue raising capacity or per capita expenditure or even the priority of the state in regard to transfers.

Table 4: Measures of inequality

\begin{tabular}{|c|c|c|c|c|}
\hline Index & \multicolumn{4}{|c|}{ Process 1: Coefficient of variation } \\
\hline Variable & Estimate & STE & LB & UB \\
\hline PCOR & 1.053 & 0.072 & 0.911 & 1.194 \\
\hline PCST & 0.733 & 0.074 & 0.586 & 0.879 \\
\hline PCTE & 0.722 & 0.061 & 0.602 & 0.842 \\
\hline Index & \multicolumn{4}{|c|}{ Process 2: Generalized Entropy index (Parameter Theta=1) } \\
\hline Variable & Estimate & STE & LB & UB \\
\hline PCOR & 0.419 & 0.041 & 0.338 & 0.500 \\
\hline PCST & 0.255 & 0.033 & 0.190 & 0.321 \\
\hline
\end{tabular}


Growing Dependence on Transfers and Rising Disparity in Municipal Finances in India:

\begin{tabular}{|c|c|c|c|c|}
\hline PCTE & 0.215 & 0.027 & 0.161 & 0.269 \\
\hline Index & \multicolumn{4}{|c|}{ Process 3: Generalized Entropy index (Parameter Theta=2) } \\
\hline Variable & Estimate & STE & LB & UB \\
\hline PCOR & 0.554 & 0.075 & 0.405 & 0.702 \\
\hline PCST & 0.268 & 0.054 & 0.161 & 0.376 \\
\hline PCTE & 0.261 & 0.044 & 0.174 & 0.347 \\
\hline Index & \multicolumn{4}{|c|}{ Process 4: Atkinson index (Parameter epsilon = 5) } \\
\hline Variable & Estimate & STE & $\mathbf{L B}$ & UB \\
\hline PCOR & 0.204 & 0.018 & 0.168 & 0.239 \\
\hline PCST & 0.139 & 0.016 & 0.107 & 0.171 \\
\hline PCTE & 0.110 & 0.013 & 0.085 & 0.136 \\
\hline Index & \multicolumn{4}{|c|}{ Process 4: Gini index } \\
\hline Variable & Estimate & STE & LB & UB \\
\hline PCOR & 0.495 & 0.022 & 0.451 & 0.539 \\
\hline PCST & 0.377 & 0.024 & 0.330 & 0.425 \\
\hline PCTE & 0.358 & 0.021 & 0.316 & 0.400 \\
\hline
\end{tabular}

Note: PEOR: Per Capita Own Revenue Receipts; PCST: 'Per Capita State Transfers; PCTE: Per Capita Total Expenditure; STE: Standard Error; LB: Lower bound; UB: Upper bound. Source: [2], [3]

Here all the measures said that the diversity exists across states for all the variables and in case of per capita own revenue the picture is more diverged in compare with other two variables. When we take the parameter value 2, the entropy index says that the estimate for per capita own revenue inflates in comparison with other two.

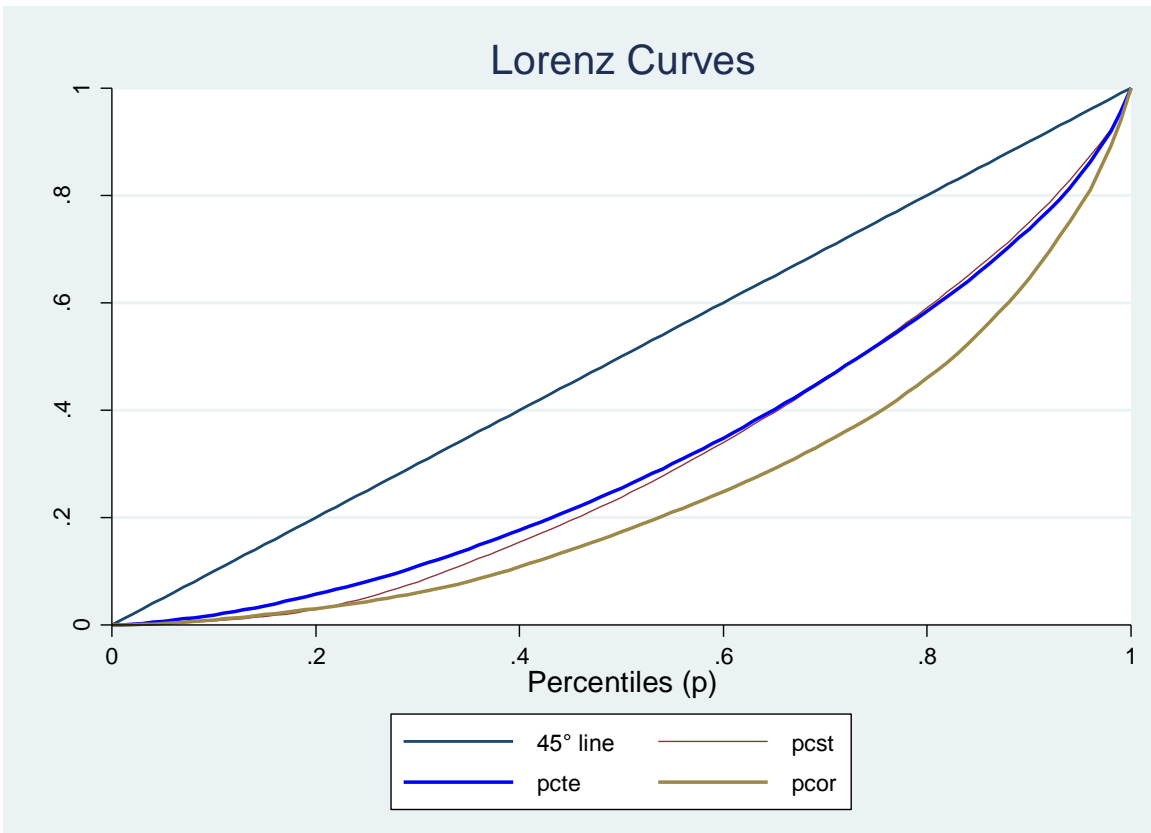

Source: Table 4

Figure 4: Lorenz curves for the three variables 
Financial management quality of the urban local bodies is too diverged and as discussed- the main responsibility of such unevenness lies in the inequality in terms of per capita own revenue- as also evident from the Lorenz curves plotted in Figure 4. Therefore, the argument is proved once again that the internal inefficiency of the ULBs are much more responsible for their poor performance, and rising dependence upon state government. Before talking about the state transfer and all states first should take care of tax revenue of the urban local bodies.

\section{The way forward}

Keeping in mind the pace of urbanization and the expected contribution of the urban centers to the GDP, it is quite clear that the though ULBs are becoming increasingly important in the wake of general trends in decentralization and urbanization but the fiscal health of the ULBs has been deteriorating in the recent years. Review of literature suggested that in most of the cases in India, decentralization reforms had limited local governments' ability to deliver the newly devolved services largely because they were not matched by the corresponding revenue generating capacity that were needed to maintain those reforms. Above all, the ULBs eventually became dependent on the state transfers, more so after the abolition of Octroi, as there were no prudent revenue handle that could have substituted the revenue lost due to abolition of Octroi. Not to forget that taxes on property and taxes on the entry of goods into a local area for consumption, use or sale therein (octroi) formed the backbone of municipal tax base. Between the two, municipal governments historically showed a preference for indirect taxes and levies like octroi compared to direct taxes such as taxes on lands and buildings, even when the latter were rated to be suitable forms of taxation on account of its incidence being localized. Taxes on the entry of goods into a local area (octroi) were among the more buoyant and elastic of the local taxes but on account of the cascading effects, have been abolished countrywide with the exception of municipal corporations in Maharashtra.

As evident from the above analysis that only few states could actually keep pace with urbanization in regard to their expenditure trends during the study years. It should be important to note at this point that Mumbai or Maharashtra is an exception in terms of progress at least in the area of urban finance. So any analysis should treat it separately or as an outlier, else there is enough room to arrive at biased results. The disparity in own revenue mainly accrues from the low or rather poor revenue generating capacity of the small ULBs that simply are surviving on the transfers. The magnitude and urgency of fiscal problems that these ULBs are experiencing are indeed a cause for concern. In future however, it will be important to broaden the focus of attention to examine smaller governments that are facing fiscal distress- for many of them are even unable to pay their salaries! Unlike major urban centers they are less likely to receive substantial attention from the higher tier- and this is where the key to revive the urban economy lies.

Lastly, there is enough possibility and hope that might states would consider alternatives that go beyond traditional policies of capacity building, mandates and annexation. Given the likelihood that present 'one diet suits for all' kind of managerially oriented policies may be ineffective in a large number of distressed ULBs at least in India. The question then is would the higher tier governments reconsider their roles in the direct provision of services to citizens? Above all, what would be the implications for these ULBs if, say at any point of time, state government bypass the distressed sub-state units in certain service area- for reasons like cost disadvantage etc? One possible scenario to overcome such puzzles is for the states to assume a welfare mentality toward some municipal governments that merit long term attention and fiscal aid by the state, rather then relying endlessly on the ad-hoc policies.

\section{References}

[1]. Government of India, Report on Indian Urban Infrastructure and Services ( RIUIS), Report submitted by the High Powered Expert Committee (HPEC) for Estimating the Investment Requirement for Urban Infrastructure Services under the chairmanship of Isher J.Ahluwalia, Ministry of Urban Development, Government of India, 2011, New Delhi.

[2]. Government of India, Report of the Twelfth Finance Commission, Ministry of Finance, Government of India, 2004, New Delhi

[3]. Government of India, Report of the Thirteenth Finance Commission, Ministry of Finance, Government of India, 2009, New Delhi.

[4]. Oates, Wallace, Fiscal Federalism, Harcourt Brace 1972, Jovanovich Inc.

[5]. Mohanty, P.K. et.al, Municipal Finances in India- An Assessment, Department of Economic Analysis \& Policy, Reserve Bank of India, 2007, Mumbai.

[6]. Ter-Minassian, Teresa, Intergovernmental Fiscal Relations in a Macro Economic Perspective, in Teresa Ter-Minassian, Fiscal Federalism in Theory and Practice, International Monetary Fund, 1977, Washington.

[7]. Rao, Govinda \& Nirvikar Singh (2004): 'Asymmetric Federalism in India', UC Santa Cruz International Economics Working Paper No. 04-08, April,Available at SSRN: http://ssrn.com/abstract=537782, 2004, New Delhi

[8]. Musgrave, Richard, The Theory of Public Finance, McGraw Hill, 1959, New York.

[9]. Gramlich, E., Intergovernmental Grants: a Review of Empirical Literature, in W.E.Oates (1977), The Political Economy of Fiscal Federation, Lexington,1977, Mass: Health.

[10]. Shah, Anwar, A Linear Expenditure Estimation of Local Fiscal Response to Provincial Transportation Grants, 1989, Kentucky Journal of Economics and Business Vol .9 (1). 
[11]. Mathur, O.P, Debdulal Thakur, Nilesh Rajadhyaksya, Urban Property Tax Potential in India, National Institute of Public Finance \& Policy (NIPFP), 2009, New Delhi

[12]. Government of India, Indian Public Finance Statistics (IPFS) 2009-2010, Ministry of Finance, Department of Economic Affairs, 2009, New Delhi.

[13]. Website of the Central Statistical Organization (CSO), www.mospi.nic.in, Government of India, New Delhi.

[14]. Cowell, F.A., Measuring Inequality ( ${ }^{\text {nd }}$ edition). Harvester Wheatsheaf, 1995, Hemel Hempstead.

[15]. Census of India, Population Projections for India and States 2001-2026 (Revised December 2006), Office of the Registrar General \& Census Commissioner, 2001,New Delhi. 